\title{
Control of Ipomoea grandifolia and antioxidant enzyme activity with bentazon and glyphosate at times and soil water conditions
}

\author{
Helis Marina Salomão, Michelangelo Müzell Trezzi, Fortunato de Bortoli Pagnoncelli Junior, Adriano \\ Suchoronczek, Matheus Viecelli and Katia Cristina Dalpiva Hartmann
}

Federal University of Technology (UTFPR), Pato Branco, PR Brazil. Correspondence to: helissalomao@gmail.com

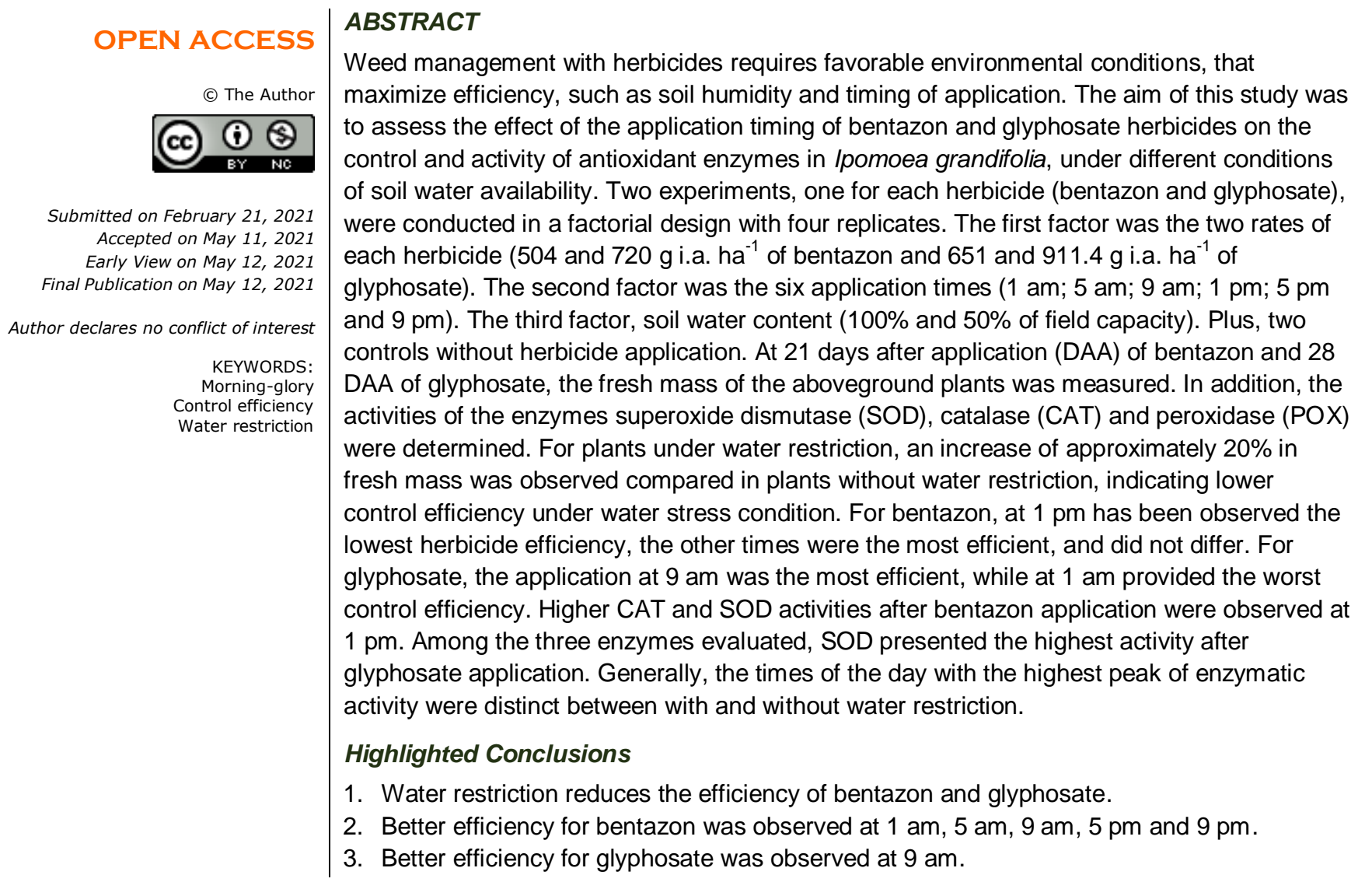

\section{INTRODUCTION}

The use of herbicides to control weeds has contributed to the intensification of agriculture worldwide, increasing yields by reducing weed competition. To maximize weed control, high efficiency application is required to avoid wasted spraying under inadequate conditions (Vitorino and Martins 2012; Lima 2015). The determination of appropriate application times is dependent on several factors, intrinsic to each region. Distinct conditions of humidity, temperature, radiation, which influence the plant's physiological activity, determine the best time for herbicide application (Oliveira Jr. and Constantin 2001; Sharma and Singh 2001; Klar et al. 2015; Gomes and Juneau 2016).

The time of herbicide application influences weed control. In night-time applications of lactofen at 5 am and 10 pm, weed control was more efficient than at $9 \mathrm{am}, 2 \mathrm{pm}$ and $5 \mathrm{pm}$ (Ferreira et al. 1998). Diquat was more efficient in nocturnal application to control Eichlornia crassipes (Pitelli et al. 2011). Better control levels of clomazone+amethrin, sulfentrazone and tebuthiuron on different weeds was observed on plants under favorable growing conditions (Souza et al. 2014). Similar results were observed for glyphosate and different ACCase inhibitor herbicides (Ramsey et al. 2005; Mohr et al. 2007; Cieslik et al. 2013, 2014, 2017). 
Herbicides affect specific biochemical pathways in plants and therefore distinct mechanisms respond differently to changes in physiological activity throughout the day, which reflects on levels of weed control (Xavier 2018). Therefore, it is essential to consider the plants physiological activity at the moment of herbicide application (Darmanti et al. 2016). In addition, adverse environmental conditions such as the occurrence of periods of water stress and high solar radiation are common, which influence the physiological response of plants and their response to herbicides (Ramsey et al. 2005).

Water deficit and the consequent physiological changes, can reduce herbicide efficiency by changing the amount and composition of epicuticular waxes in leaves (Hatterman-Valentti et al. 2011; Willick et al. 2017; Trezzi et al. 2020) and/or by reducing herbicide uptake and translocation (Alizade et al. 2020; Santos et al. 2021).

Plants that are under stress naturally produce reactive oxygen species (ROS), which can lead them to death due to lipid peroxidation and membrane disruption (Huang et al. 2013; Suchoronczek 2016). However, plants under some level of stress have active antioxidant mechanisms and, after herbicide application, show more conditions to metabolize the free radicals produced (Darmanti et al. 2016), contributing to the reduction of herbicide efficiency. This antioxidative complex includes the enzymes superoxide dismutase (SOD), ascorbate peroxidase (APX), catalase (CAT) and peroxidase (POX) and is considered the first defense mechanism triggered by plants against oxidative stress (Mittler 2002; Xavier 2018). This defense mechanism has a crucial role in free radical detoxification, the action can occur in different cellular compartments and at different times (Hwang et al. 1999; Bajji et al. 2007; M'hamdi et al. 2009; Suchoronczek 2016; Xavier 2018).

An important question to be answered is whether herbicide application at more favorable times of day would be able to overcome physiological barriers and antioxidant mechanisms generated by environmental stress, improving herbicide control efficiency. Thus, more information is needed about weed control under conditions without and with water stress in applications at different times of the day. The interaction of these two factors, soil moisture and time of application can provide important information for technical assistance and farmers.

The aim of this study was to assess the effect of the application timing of bentazon and glyphosate herbicides on the control and activity of antioxidant enzymes in Ipomoea grandifolia, under different conditions of soil water availability.

\section{MATERIAL AND METHODS}

The work was carried out in greenhouse of the Federal University of Technology - Parana (UTFPR), Campus Pato Branco (261' 54.1 " S and 5241'26.2" W). The average, minimum and maximum temperature data for the whole experimental period are shown in Figure 1. The soil (Type "Nitossolo Vermelho Distrófico") was collected in a cultivated area and the chemical and physical properties are listed in Table 1. The soil was dried in greenhouse until reaching constant mass in order to fill the 5 litre pots volume. The inner base of the pots was lined with drainage blanket to prevent soil loss.

Two experiments, one for bentazon and the other for glyphosate, were performed in a $2 \times 6 \times 2(+2)$ factorial scheme with four replicates. The first factor corresponds to two doses of each herbicide (bentazon: 504 and $720 \mathrm{~g}$ i.a. ha ${ }^{-1}$ and glyphosate: 651 and $911.4 \mathrm{~g}$ i.a. ha ${ }^{-1}$ ), previously defined in a dose trial for the biotype used; the second factor by six application times ( $1 \mathrm{am} ; 5 \mathrm{am} ; 9 \mathrm{am} ; 1 \mathrm{pm} ; 5 \mathrm{pm}$ and $9 \mathrm{pm}$ ); and the third by soil moisture (100 and $50 \%$ of field capacity). In addition, two non-applied controls were included, one for each water condition.

Seeds of $I$. grandifolia from the germplasm of NIPED ("Núcleo de Investigações na Ciência das Plantas Daninhas" of UTFPR, Campus Pato Branco), with $70 \%$ germination were used in the experiments. Seed dormancy was overcome by the hot water treatment method, according to Pazuch et al. (2015). Ten I. grandifolia seeds were sown per pot and at three and 10 days after emergence, thinning was carried out, leaving four plants per pot. When the plants reached two to four true leaves, the herbicides were sprayed. The application was done using a $\mathrm{CO}_{2}$ backpack sprayer equipped with XR110.02 fan spray at volume of $200 \mathrm{~L} \mathrm{ha}^{-1}$. Photosynthetically active radiation (PAR) was measured with a bar photometer (Li-191R, Licor, Lincoln, USA) (Table 2).

Field capacity was determined by weighing saturated soil, subsequently oven-dried and re-weighed (Scherer 2017). Soil humidity was maintained at $100 \%$ of field capacity from the sowing of $I$. grandifolia until ten days prior to the herbicides application, when the desired humidity was assigned to each treatment. Soil moisture was controlled by replacing the water loss in the amount necessary to reach $50 \%$ and $100 \%$ of field capacity.

At 21 days after application (DAA) of bentazon and 28 DAA of glyphosate, vegetal material was collected to determine the fresh mass of the aboveground.

At 24 hours after bentazon application (Nohatto et al. 2016) and 96 hours after glyphosate application (Moldes et al. 2008) vegetal material was collected for quantification of the activity of oxidative stress enzymes, dismutase (SOD), catalase (CAT) and peroxidase (POX). Approximately $1 \mathrm{~g}$ of vegetal material (fully expanded leaves from 
the upper third of the plant) was collected and packed in aluminum foil envelopes, quickly frozen with liquid nitrogen, and stored at $-20^{\circ} \mathrm{C}$ until the time of analysis.

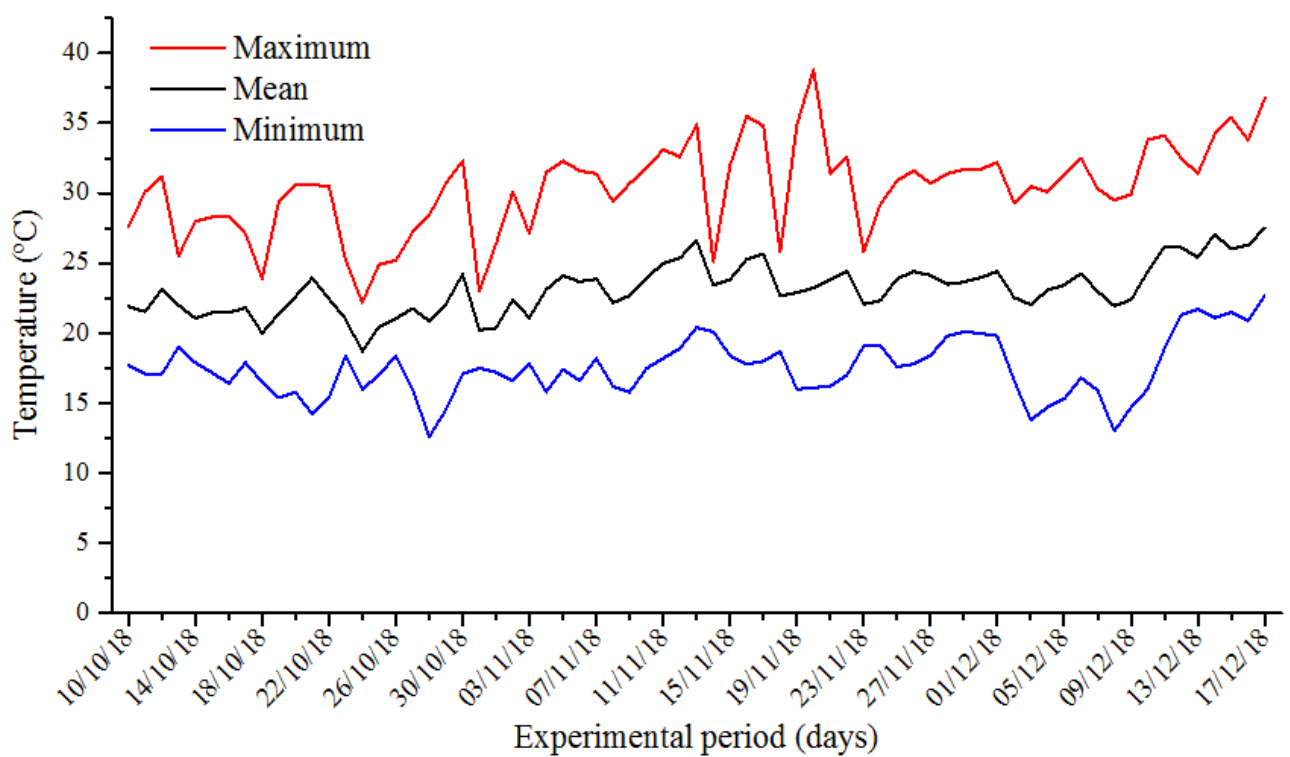

Figure 1. Temperature during the period of conduction of the experiment.

Table 1. Chemical and physical properties of the soil in the $\mathbf{0}$ to $\mathbf{2 0} \mathrm{cm}$ layer.

\begin{tabular}{|c|c|c|c|c|c|c|c|c|c|c|c|c|}
\hline $\mathrm{pH}$ & OM & $\mathrm{Al}^{3+}$ & $\mathrm{H}+\mathrm{Al}$ & $\mathrm{Ca}^{2+}$ & $\mathrm{Mg}^{2+}$ & $\mathrm{K}$ & SB & $P$ & V & Sa & $\mathrm{Si}$ & $\mathrm{Cl}$ \\
\hline $\mathrm{CaCO}_{3}$ & $\mathrm{gdm}^{-3}$ & \multicolumn{6}{|c|}{$\mathrm{cmol}_{\mathrm{C}} \mathrm{dm}^{-3}$} & $\mathrm{mg} \mathrm{dm^{-3 }}$ & \multicolumn{4}{|c|}{$\%$} \\
\hline 5.20 & 24.1 & 0.0 & 5.7 & 6.6 & 3.6 & 0.3 & 10.5 & 16.2 & 64.6 & 18.0 & 18.0 & 64.0 \\
\hline
\end{tabular}

OM: Organic matter; SB: Sum of bases; V: base saturarion; Sa: Sand; Si: Silt; Cl: Clay

Table 2. Photosynthetically active radiation (PAR) and temperature at each time of application of herbicides.

\begin{tabular}{ccc}
\hline Times & PAR $\left(\mu \mathrm{mol} \mathrm{m}^{-2} \mathrm{~s}^{-1}\right)$ & Temperature $\left({ }^{\circ} \mathrm{C}\right)$ \\
\hline $1 \mathrm{am}$ & 0.0 & 17.9 \\
$5 \mathrm{am}$ & 0.0 & 16.0 \\
$9 \mathrm{am}$ & 271.7 & 27.4 \\
$1 \mathrm{pm}$ & 581.0 & 29.6 \\
$5 \mathrm{pm}$ & 315.0 & 26.4 \\
$9 \mathrm{pm}$ & 0.0 & 20.2 \\
\hline
\end{tabular}

For the enzymatic analysis we used an extraction buffer constituted by $100 \mathrm{mM}$ of TKP (potassium phosphate buffer) with $\mathrm{pH}$ adjusted in 7.5, added of $1 \mathrm{mM}$ of EDTA, $5 \mathrm{mM}$ of DTT (dithiothreitol) and $1 \%(\mathrm{~m} / \mathrm{v})$ of PVP (polyvinylpyrrolidone). $8 \mathrm{~mL}$ of extraction buffer was employed for each $1 \mathrm{~g}$ of vegetal material. Maceration was performed using liquid $\mathrm{N}$ and the material was centrifuged for $10 \mathrm{~min}$ at $4^{\circ} \mathrm{C}$ at $12,000 \mathrm{x}$. The precipitate was eliminated and the supernatant stored at $-20^{\circ} \mathrm{C}$, subsequently used as enzyme extract.

The quantification of CAT activity (EC: 1.11.1.6) was performed according to the methodology of Shabala and Cuin (2012). The POX (EC: 1.11.1.7) and the activity was determined according to Flurkey and Jen (1978) with substrate concentrations following suggestions of Cakmak and Horst (1991) and Srivastava and Dwivedi (2000). The SOD activity (EC: 1.15.1.1) was determined according to the methodology proposed by Giannopolitis and Ries (1977). The protein content was determined using the methodology proposed by Bradford (1976).

All the data collected were compared with controls without herbicide application. The plant material used to determine the enzymatic activity was collected at the time of their respective treatments, together with the controls, thus isolating the effect of higher activity caused by the hottest hours of the day.

The data obtained were submitted to analysis of variance (ANOVA) and when significant ( $p \leq 0.05)$, the means were compared by Tukey's test $(p \leq 0.05)$ using the package "ExpDes.pt" with R software (Ferreira et al. 2018). Graphs were constructed with Sigma Plot 11.0 software.

\section{RESULTS AND DISCUSSION}

Experiment with bentazon. In the treatments with bentazon, there was no difference between the doses, therefore the dose data have been pooled. The fresh mass of $I$. grandifolia plants with water restriction did not differ 
from the control (with water restriction) without herbicide application. Plants without water restriction had a reduction in fresh mass compared to the control (without water restriction) (Figure 2). Plants in optimum water conditions keep their metabolism in full operation and have no additional impediments to herbicide uptake and translocation, tending to be more affected by herbicides when compared with plants under water stress. This reduction in plants without water restriction was similar to the results of Roman et al. (2003), Oliveira Jr. et al. (2006), Pereira et al. (2010), Souza et al. (2014) and Klar et al. (2015), who observed lower fresh mass in plants under water restriction.

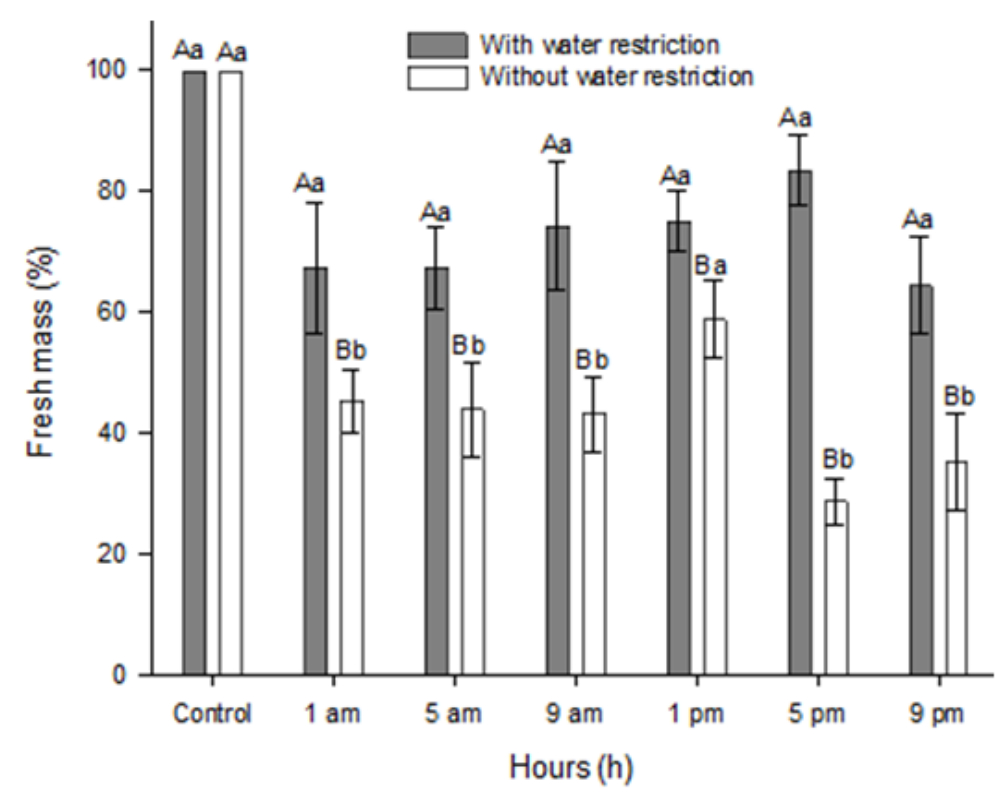

Figure 2. Fresh mass (\%) of Ipomoea grandifolia plants, at 21 DAA, affected by the interaction between times of bentazon application and soil water conditions. *Bars show the mean standard error. Columns with capital letters compare among times and lowercase letters between restrictions, equal letters do not differ by Tukey's test ( $p \leq 0.05)$.

The application of bentazon at $1 \mathrm{pm}$ had the lowest efficiency of the herbicide compared with the other application times (Figure 2). The time of $1 \mathrm{pm}$ coincided with the highest temperature and photosynthetically active radiation of the day (Table 2). Times when higher temperatures and greater solar radiation occur are the most critical for plants, reducing the activity of primary metabolism, and consequent paralysis in the processes and absorption and transport of substances (Bastos et al. 2012), such as herbicides.

Plants of $I$. grandifolia under water restriction did not show differences in fresh mass among application times. This can be explained by the fact that water deficiency severely compromises different functions essential in the plant, limiting leaf expansion, reducing the photosynthetic rate, stomatal closure, as well as reducing defense mechanisms and the accumulation of biomass (Ramsey et al. 2005). Thus, the application of bentazon at times with low temperature and irradiance, when primary metabolism is most active, did not improve the efficacy of the herbicide on I. grandifolia due to the effects caused by water restriction. Photosystem II inhibitory herbicides trigger oxidative stress reactions due to disruption of electron flow between photosystems (Caverzan et al. 2019). However, in antioxidant enzymes, there was no effect for POX, possibly because it was not in fully activity at the time of sample collection, but the activity of CAT in plants of $I$. grandifolia with water restriction, treated with bentazon at $1 \mathrm{pm}$, was 4 times higher than in the control plants (with water restriction and without herbicide). The activity of this enzyme in plants without water restriction was similar between the times of application, but in all cases, the activity was lower than that observed in the control. At all application times the CAT activity of plants with water restriction ( 80 to $160 \%$ from 5 am to $9 \mathrm{pm}$ ) exceeded the activity of plants without water restriction (30$60 \%$ ), except at $1 \mathrm{am}$, which did not differ (Figure $3 \mathrm{~A}$ ).

The activity of SOD in plants under water restriction was higher at $1 \mathrm{pm}(120 \%)$, while at the other times, the activity of this enzyme was similar, oscillating from 70 to $90 \%$. For the plants without water restriction, the highest SOD activity occurred at 1 am and $9 \mathrm{pm}$ (87 and 95\%, respectively) and with lower values at $1 \mathrm{pm}$ and $5 \mathrm{pm}$ hours $(55$ and $50 \%)$. At these times, the greatest differences were observed in the activity of this enzyme between plants with and without water restriction (Figure 3B). 

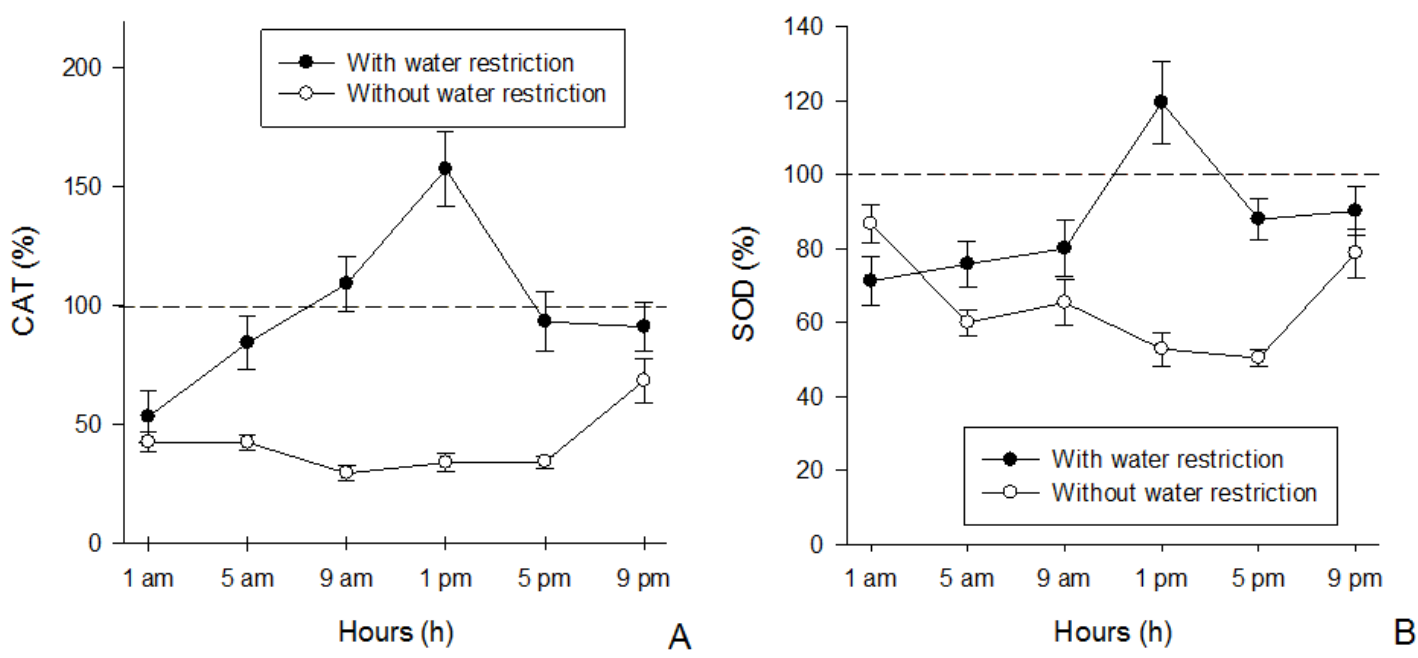

Figure 3. Activity of the enzymes CAT (A) and SOD (B) in Ipomoea grandifolia plants subjected to bentazon application at different times and soil water conditions. * Dashed line indicates the enzymatic activity of the control without herbicide application. Bars denote the mean standard error.

The higher activity of SOD and CAT enzymes in plants under water restriction may be due to the fact that stressed plants produce a higher amount of ROS (Caverzan et al. 2019), and since water restriction was initiated 10 days before herbicide application, the enzyme machinery was stimulated, making it more efficient in detoxifying the ROS produced after herbicide application. Moreover, CAT and SOD showed higher activity when plants were treated at $1 \mathrm{pm}$, that time coincides with the highest incidence of solar radiation, which increased the formation of chlorophyll triplet and the production of superoxide, due to the mode of action of bentazon, inhibiting the transfer of electrons from quinone A to B in photosystem II (Taiz et al. 2017). This increase in the production of ROS is reflected in an increase in the activity of the enzymes SOD and CAT, since plants under water restriction show greater activity of the antioxidant system.

Experiment with glyphosate. The fresh mass of $I$. grandifolia plants treated with glyphosate was reduced by more than $90 \%$ relative to the control in both water restrictions (Figure 4). The high efficiency of this herbicide reduced differences among the application times. Differences between doses were observed only for SOD. A higher reduction in plant fresh mass was observed when the application occurred at 9 am in relation to 1 am. Daytime applications of glyphosate contribute to better herbicide effectiveness, because to photosynthetic activity and amino acid synthesis pathways being in operation due to the presence of light (Santos Jr et al. 2013; Sharkhuu et al. 2014; Vidal et al. 2014). Applications taken between 9 am and 6 pm provide greater glyphosate efficiency (Martinson et al. 2005).

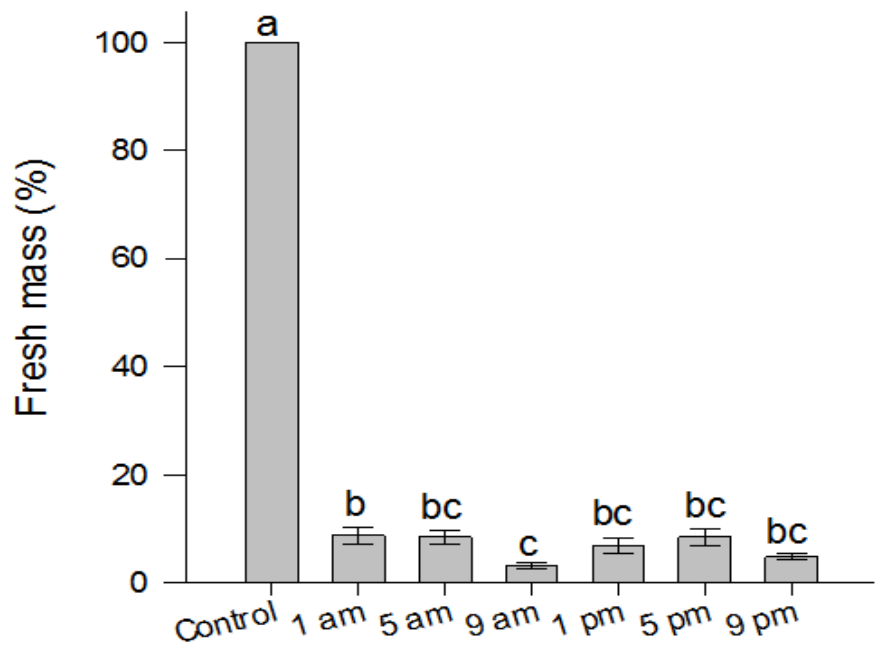

Hours (h)

Figure 4. Fresh mass of Ipomoea grandifolia plants at 28 DAA subjected to glyphosate application at different times of the day. *Bars denote the mean standard error. Columns followed by the same letter do not differ statically by Tukey's test ( $p \leq 0.05)$. 
In relation to soil moisture, glyphosate caused less reduction in fresh mass in $I$. grandifolia under water restriction (Figure 5). Similar results in various weed species were observed by Zanatta et al. (2007) and Silva Jr. et al. (2018). The reduction in efficiency occurs due to lower herbicide absorption and translocation due to morphophysiological changes (Vitorino and Martins 2012), such as thickening and composition of epicuticular wax, leaf pilosity, reduced water potential and modification of leaf orientation (Levene and Owen 1995; Vidal et al. 2014; Trezzi et al. 2020). Different studies have reported that glyphosate is more efficient when applied at 6 am (Mohr et al. 2007), and temperatures near to $25^{\circ} \mathrm{C}$ (Degreeff et al. 2018). Applications made under temperatures below $20^{\circ} \mathrm{C}$ provided lower uptake and translocation, therefore lower herbicide efficiency (Nguyen et al. 2016; Ou et al. 2018).

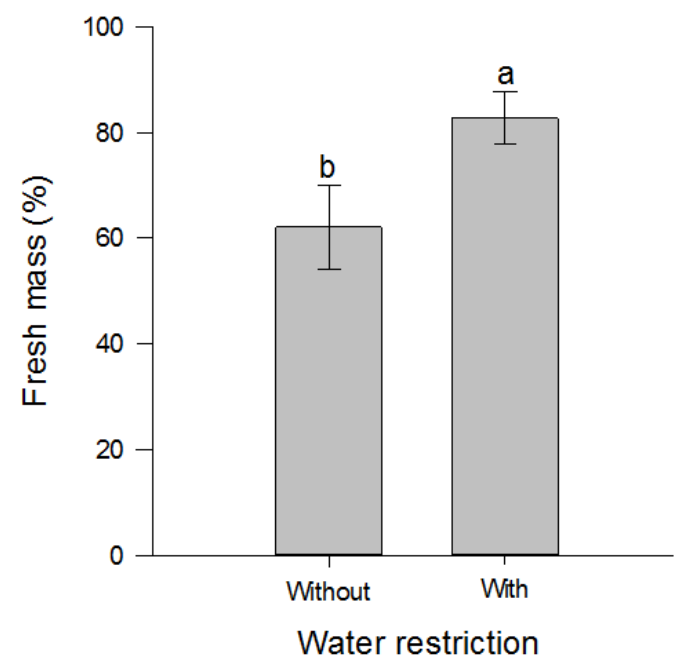

Figure 5. Fresh mass (\%) of Ipomoea grandifolia plants subjected to glyphosate application in different soil water conditions. *Bars denote the mean standard error. Columns followed by the same letter do not differ statically by Tukey's test $(p \leq 0.05)$.

In this study, temperatures at 1 and 9 am were 17.9 and $27.4^{\circ} \mathrm{C}$, respectively (Table 2). These temperatures contribute to explain the better efficiency of the herbicide at $9 \mathrm{am}$. The application at 1 am occurred in the absence of solar radiation, while the RFA at 9 am was $271.70 \mu \mathrm{mol} \mathrm{m}^{-2} \mathrm{~s}^{-1}$ (Table 2), which probably contributed to the higher efficiency of the herbicide at this time.

The enzymatic activity of CAT and POX of $I$. grandifolia plants with or without water restriction was lower compared to the control (with water restriction and without herbicide) in most cases, regardless of the time of glyphosate application. However, peaks of activity of these enzymes were observed at determined times of the day, according to the soil water condition. The highest peak of CAT activity $(110 \%)$ was observed at 1 am, followed by 9 am and $1 \mathrm{pm}$ ( 80 and $85 \%$, respectively) for plants under water restriction. At 5 am and $9 \mathrm{pm}$ was observed the lowest activity of this enzyme (55-60\%). In plants without water restriction, the highest activity of CAT occurred at 1, 5 and $9 \mathrm{pm}$ (95-100\%), while the lowest occurred at 1 and 9 am (60 and 40\%, respectively) (Figure 6A).

The POX activity was reduced in relation to the control with and without water restriction at the majority of the times evaluated, with the exception of $5 \mathrm{am}$. The activity of this enzyme was lower in plants with water restriction than in plants without restriction. The lowest POX activity (\%) was observed in plants under water restriction when the application was at $9 \mathrm{am}$, increasing up to $40 \%$ at $1 \mathrm{am}$ and $9 \mathrm{pm}$. In plants without water restriction, the highest peak of POX activity (95\%) was observed at $5 \mathrm{am}$, and the lowest activity $(25 \%)$ at $1 \mathrm{am}$. At the other application times, the activity of this enzyme oscillated from 40 to $70 \%$ with no differences among times (Figure 3B).

In plants without water restriction, CAT and POX activities showed a similar pattern, whereas in plants with water restriction, POX enzyme activity was more negatively affected than CAT enzyme activity. The SOD activity (Figure 7) in response to the application times and soil water conditions followed a similar pattern to the CAT activity in both water conditions.

In plants under water restriction, peaks of SOD activity were observed at 1 am and $1 \mathrm{pm}$, surpassing the control without herbicide. This last time (1 pm) coincides with the maximum evapotranspiration demand of the plants, when the effect of water stress is accentuated. In plants without water restriction the peaks of SOD activity also exceeded the control without herbicide. However, differences in the activity of SOD were observed at 5 am and $5 \mathrm{pm}$, depending on the dose applied. At $1 \mathrm{am}, 9 \mathrm{am}$ and $1 \mathrm{pm}$, the treatment with water restriction showed superior 
activity with the smallest dose of herbicide, while without water restriction there was a higher activity of SOD at the highest dose, at 5 and 9 am and 5 pm the opposite was observed.
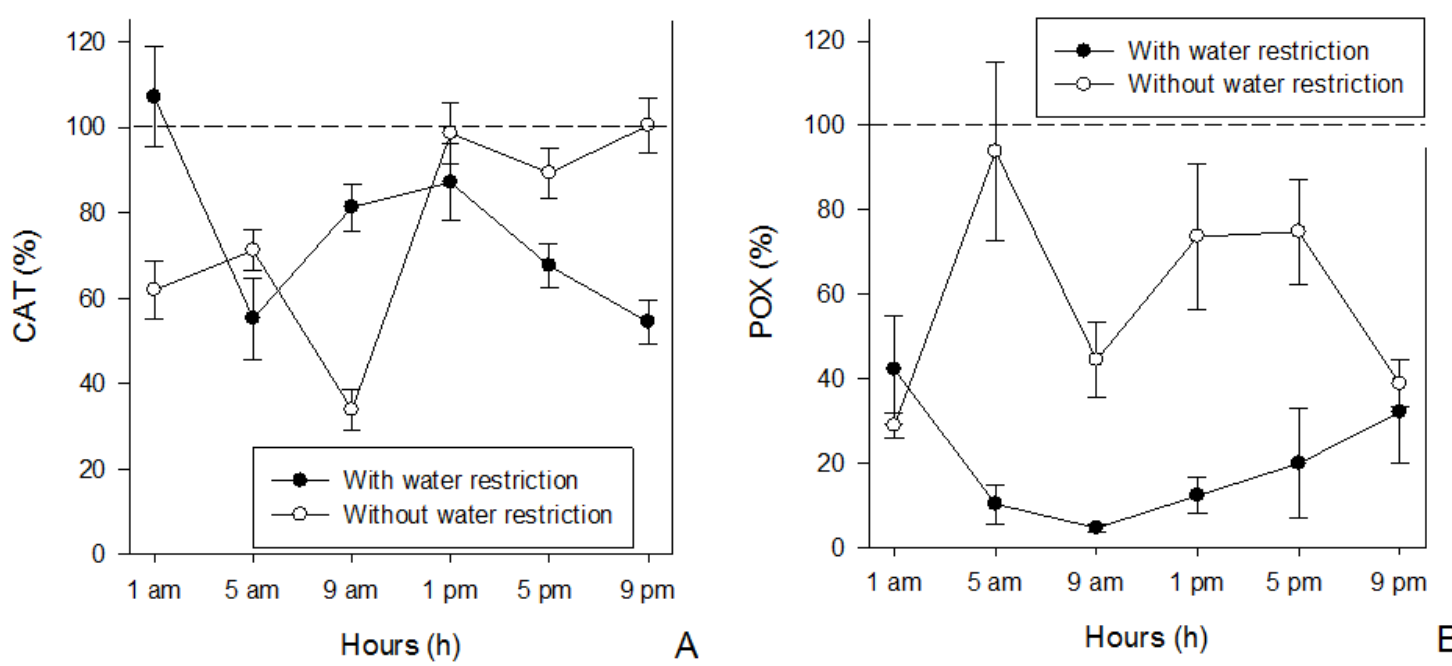

Figure 6. Activity of CAT (A) and POX (B) enzymes in Ipomoea grandifolia plants subjected to glyphosate at different application times and soil water conditions. * Dashed line indicates the enzymatic activity of the control without herbicide application. Bars denote the mean standard error.

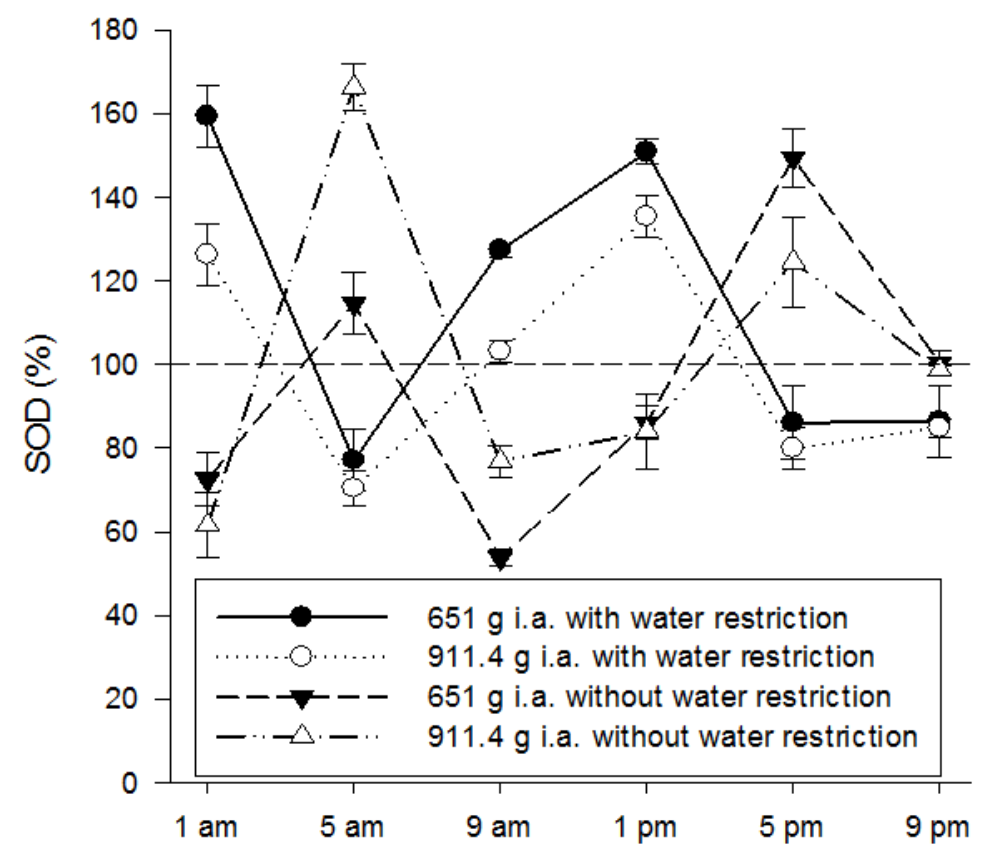

Figure 7. SOD enzyme activity in Ipomoea grandifolia plants subjected to application of different doses of glyphosate, at different times of application and soil water conditions. * Dashed line indicates the enzymatic activity of the control without herbicide application. Bars denote the mean standard error.

Increased antioxidant enzyme activity has been reported in plants subjected to glyphosate application (Ahsan et al. 2008; Miteva et al. 2010; Caverzan et al. 2019). The alteration in the expression of these enzymes is an important factor for the occurrence of plants resistant to this herbicide (Maroli et al. 2015; Gomes et al. 2016). Blocking shikimic acid synthesis leads to paralysis in plant growth, in addition to elevating the production of ROS, altering $\mathrm{H}_{2} \mathrm{O}_{2}$ metabolism and elevating the activity of enzymes such as SOD and CAT (Silva et al. 2017).

In the absence of water restriction, different genotypes of soybean susceptible to glyphosate showed a reduction in CAT activity 72 hours after herbicide application (Moldes et al. 2008), corroborating the data observed in this study.

The higher enzymatic activity at certain times of application could be related to the greater absorption of the herbicide, which could induce a greater oxidative response in the plant. The activity of detoxifying enzymes may contribute to the reduction of herbicide phytotoxicity in the plant, making it less sensitive (Sergiev et al. 2006). In 
the present study, this effect was not observed, because the activity of POX decreased sharply in the treatments with water restriction, in almost all the times of application. It is possible that the low activity of this enzyme, especially under water stress, may be explained by the doses of glyphosate used in this study, which generated high phytotoxicity to the plants, damaging their antioxidant metabolism.

Finally, in I. grandifolia plants under water restriction, the herbicides bentazon and glyphosate show lower control efficiency. The efficiency of glyphosate was improved when the application was made at 9 am, regardless of the water condition. Regardless of the times evaluated, satisfactory control efficiency was observed with bentazon, except at $1 \mathrm{pm}$ for plants under water restriction. The highest CAT and SOD activities occurred at $1 \mathrm{pm}$ for the bentazon herbicide. In general, the peak times of enzymatic activity were distinct between with and without water restriction.

\section{References}

Ahsan N et al. 2008. Glyphosate induced oxidative stress in rice leaves revealed by proteomic approach. Plant Physiol. Biochem. 46:10621070.

Alizade S et al. 2020. Effect of water deficit stress on benzoylprop-ethyl performance and physiological traits of winter wild oat (Avena sterilis subsp. ludoviciana). Crop Protection 137:105292.

Bajji M et al. 2007. Catalase inhibition alters suberization and wound healing in potato (Solanum tuberosum) tubers. Physiologia Plantarum 129:472-483.

BAstos EA et al. 2012. Parâmetros fisiológicos e produtividade de grãos verdes do feijão-caupi sob déficit hídrico. Water Resourcesand Irrigation Management 1:31-37.

Bradford MM. 1976. A rapid and sensitive method for the quantitation of microgram quantities of protein utilizing the principle of protein-dye binding. Analytical Biochemistry 72:248-254

Cakmak I and Horst WJ. 1991. Effect of aluminium on lipid peroxidation, superoxide dismutase, catalase, and peroxidase activities in root tips of soybean (Glycine max). Physiologia Plantarum 83:463-468.

Caverzan A et al.2019. Defenses against ROS in crops and weeds: The eff ects of interference and herbicides. Journal of Molecular Science $20: 1086$.

Cieslik LF et al. 2013. Environmental factors affecting the efficacy of ACCase-inhibiting herbicides: a review. Planta daninha. 31:483-489.

Cieslik LF et al. 2014.Fomesafen toxicity to bean plants as a function of the time of application and herbicide dose. Acta Scientiarum. Agronomy36:329-340.

Cieslik LF et al. 2017. Fluazifop-p-butyl efficacy as a function of application time and herbicide dose. Planta Daninha 35:e017167349.

Darmanti S et al. 2016. Antioxidative defenses of soybean [Glycine max (L.) Merr. cv. Grobogan] against purple nutsedge (Cyperus rotundus L.) interference during drought stress. The Journal of Animal \& Plant Science 26:225-232.

Degreeff $\mathrm{R}$ et al. 2018. Influence of plant growth stage and temperature on glyphosate efficacy in common lambsquarters (Chenopodium album). Weed Technology 32:448-453.

Ferreira BF et al. 2018. ExpDes.pt: Pacote Experimental Designs (Portuguese). R package version 1.2.0, 2018.

Ferreira MC et al.1998. Redução da dose e do volume de calda nas aplicações noturnas de herbicidas em pós-emergência na cultura de soja. Planta Daninha, 16:25-36.

Flurkey WH and Jen JJ. 1978. Peroxidase and polyphenoloxidase activities in developing peaches. Journal of Food Science 43:1826-1828.

Giannopolitis CN and Ries SK. 1977. Superoxide dismutases: I. occurrence in higher plants. Plant Physiology 59:309-314.

Gomes MP and Juneau P. 2016.Oxidative stress in duckweed (Lemna minor L.) induced by glyphosate: Is the mitochondrial electron transport chain a target of this herbicide? Environmental Pollution 218:402-409.

Gomes MP et al.2016. Differential effects of glyphosate and aminomethylphosphonic acid (AMPA) on photosynthesis and chlorophyll metabolism in willow plants. Pesticide Biochemistry and Physiology 130:65-70.

Hatterman-Valenti $\mathrm{H}$ et al. 2011. Environmental effects on velvetleaf ( Abutilon theophrasti) epicuticular wax deposition and herbicide absorption. Weed Science 59:14-21.

Huang YW et al. 2013. Exogenous glucose regulates activities of antioxidant enzyme, soluble acid invertase and neutral invertase and alleviates dehydration stress of cucumber seedlings. Scientia Horticulturae 162:20-30.

Hwang SY et al. 1999. Reduced susceptibility to water logging together with high-light stress is related to increases in superoxide dismutase and catalase activities in sweet potato. Plant Growth Regulation 27:167-172.

Klar AE et al. 2015. Potenciais hídricos no solo sobre a eficácia de herbicidas em Cenchrus echinatus L. Irriga Especial:123-138.

Levene BC and Owen MDK. 1995. Effect of moisture stress and leaf age on bentazon absorption in common cocklebur (Xanthium strumarium) and velvetleaf (Abutilon theophrasti). Weed Science 43:7-12.

Lima MFP. 2015. Ecofisiologia de espécies de plantas daninhas submetidas a estresse hídrico e reidratação. Dissertação, Universidade Federal Rural do Semi-Árido. https://ppgfito.ufersa.edu.br/wp-content/uploads/sites/45/2015/02/Dissertac\%C3\%A3o-2015-MAYKYFRANCLEY-PEREIRA-DE-LIMA.pdf.

M'Hamdi M et al. 2009. Insight into the role of catalases in salt stress in potato (Solanum tuberosum L.). Biotechnologie Agronomie Societe et Environnement 13:373-379.

Maroli AS et al.2015. Metabolic profiling and enzyme analyses indicate a potential role of antioxidant systems in complementing glyphosate resistance in an amaranthuspalmeri biotype. Journal of Agricultural and Food Chemistry 63:9199-9209.

Martinson KB et al. 2005. Time of day of application effect on glyphosate and glufosinate efficacy. Crop Management 4:1-7

Miteva LE et al. 2010. Alterations in glutathione pool and some related enzymes in leaves and roots of pea plants treated with the herbicide glyphosate. Russian Journal of Plant Physiology 57:131-136.

Mittler R. 2002. Oxidative stress, antioxidants and stress tolerance. Trends in Plant Science 7:405-410.

Mohr K et al. 2007. Application time of day influences glyphosate efficacy. Weed Technology 21:7-13.

Moldes CA et al. 2008. Biochemical responses of glyphosate resistant and susceptible soybean plants exposed to glyphosate. Acta Physiologiae Plantarum 30:469-479. 
Nguyen TH et al. 2016. Temperature influences the level of glyphosate resistance in barnyardgrass (Echinochloa colona). Pest Management Science 72:1031-1039.

Nohatto MA et al. 2016. Antioxidant activity of rice plants sprayed with herbicides. Pesquisa Agropecuária Tropical 46:28-34.

Oliveira Jr. RS and Constantin J. 2001. Plantas daninhas e seu manejo. Guaíba: Agropecuária.

Oliveira Jr. RS et al. 2006. Influência do período de restrição hídrica na atividade residual de isoxaflutole no solo. Planta Daninha 24:733-740.

$\mathrm{Ou} \mathrm{J}$ et al. 2018. Reduced absorption of glyphosate and decreased translocation of dicamba contribute to poor control of kochia (Kochia scoparia) at high temperature. Pest Management Science 74:1134-1142.

Pazuch D et al.2015. Superação de dormência em sementes de três espécies de Ipomoea. Ciência Rural 45:192-199.

Pereira MRR et al. 2010. Efeito de herbicidas sobre plantas de Brachiaria plantaginea submetidas a estresse hídrico. Planta Daninha 28:10471058.

pitelli RA et al. 2011. Doses e horário de aplicação do diquat no controle de Eichhornia crassipes. Planta Daninha 29:269-277.

Ramsey RJL et al. 2005. A review of the effects of humidity, humectants, and surfactant composition on the absorption and efficacy of highly water-soluble herbicides Pesticide Biochemistry and Physiology 82:162-175.

Roman E et al. 2003. Efeito do teor de umidade do solo na seletividade e na eficiência de carfentrazone-ethyl no controle de plantas daninhas na cultura de soja. Revista Brasileira de herbicidas 4:114-122.

Santos Jr. A et al. 2013. Manejo da tiririca e trapoeraba com glyphosate em ambientes sombreados. Planta Daninha 31:213-221.

Santos JCC et al. 2021. Glyphosate hormesis mitigates the effect of water deficit in safflower (Carthamus tinctorius L.). Pest Management Science 77:2029-2044.

Scherer MB. 2017. Morfologia e fisiologia do capim pé-de-galinha em diferentes condições hídricas e controle sob três manejos de água. Dissertação, Universidade Federal de Santa Maria. https://repositorio.ufsm.br/handle/1/13926.

Sergiev IG et al. 2006. The phenylurea cytokinin 4PU-30 protects maize plants against glyphosate action. Pesticide Biochemistry and Physiology $85: 139-146$.

Shabala S and Cuin TA. (Eds). 2012. Plant Salt Tolerance: Methods and Protocols. Methods in Molecular Biology. Humana Press: London.

Sharkhuu A et al. 2014. A red and far-red light receptor mutation confers resistance to the herbicide glyphosate. The Plant Journal 78:916-926.

Sharma SD and Singh M. 2001. Environmental factors affecting absorption and bio-efficacy of glyphosate in florida beggarweed (Desmodium tortuosum). Crop Protection 20:511-516.

Silva FL et al. 2017.Glyphosate-induced oxidative stress in Arabidopsis thaliana affecting peroxisomal metabolism and triggers activity in the oxidative phase of the pentose phosphate pathway (OxPPP) involved in NADPH generation. Journal of Plant Physiology 218:196-205.

Silva Jr. AC et al. Effect of glyphosate on guineagrass submitted to different soil water potential. Planta Daninha 36:e018180818.

Souza $\mathrm{G}$ et al. 2014. Baixa umidade do solo na eficácia de herbicidas aplicados em pré-emergência. Bioscience Journal 30:555-562.

Srivastava MK and Dwivedi UN. 2000. Delayed ripening of banana fruit by salicylic acid. Plant Science 158:87-96.

Suchoronczek A. 2016. Qualidade pós-colheita e alterações bioquimicas de duas cultivares de batata submetidas a estresse térmico. Dissertação, Universidade Estadual do Centro-Oeste.

Taiz Let al. 2017. Fisiologia e desenvolvimento vegetal. Artmed: Porto Alegre.

Trezzi MM et al. 2020. Relationship between the amount and composition of epicuticular wax and tolerance of Ipomoea biotypes to glyphosate. Journal of Environmental Science and Health, Part B - Pesticides, Food Contaminants, and Agricultural Wastes 55:959-967.

Vidal RA et al. 2014. Fatores ambientais que afetam a eficácia de glifosato: síntese do conhecimento. Pesticidas: Revista Ecotoxicologia e Meio Ambiente 24:43-52.

Vitorino H and Martins D. 2012. Efeito do déficit hídrico na eficiência de herbicidas e nas características bioquímicas de Ipomoea grandifolia. Planta daninha 30:185-191.

Willick I $R$ et al. 2017. Wheat flag leaf epicuticular wax morphology and composition in response to moderate drought stress are revealed by SEM, FTIR-ATR and synchrotron X-ray spectroscopy. Physiologia Plantarum 162:316-332.

Xavier E. 2018. Mecanismo de tolerância a herbicidas inibidores da ALS em cultivares de Aveia branca (Avena sativa L.). Tese, Universidade Tecnológica Federal do Paraná. https://repositorio.utfpr.edu.br/jspui/handle/1/3348

Zanatta JF et al. 2007. Teores de água no solo e eficácia do herbicida glyphosate no controle de Euphorbia heterophylla. Planta Daninha 25:799-811. 